\title{
Response of rats to grapefruit flavonoids and inulin fed singly or in combination*
}

\author{
S. Frejnagel ${ }^{1}$, Z. Zduńczyk and M. Wróblewska \\ Institute of Animal Reproduction and Food Research, Polish Academy of Sciences \\ Tuwima 10, 10-747 Olsztyn, Poland
}

\begin{abstract}
Rats of an initial body weight of $124 \mathrm{~g}$ were fed for 28 days on a casein diet unsupplemented or supplemented with grapefruit flavonoids (FL) $0.3 \%$ or inulin (IN) 5 and $10 \%$, given singly or in combination. Feed intake and weight gain were registered and protein digestibility and $\mathrm{N}$ retention were determined. At the end of the experiment blood was sampled and concentrations of cholesterol (total and HDL), triacylglycerols (TAG), glucose, $\mathrm{Mg}, \mathrm{Ca}$ and $\mathrm{P}$ were determined. FL fed either alone or with IN depressed feed intake, and FL+IN10 also body gain. The supplements did not affect feed conversion or protein digestibility, $\mathrm{N}$ utilization was or tended to be higher in rats fed IN singly or with FL. FL did not affect the total cholesterol level while IN fed alone tended to decrease, and fed with FL, significantly decreased total cholesterol. Both supplements tended to decrease TAG concentration.
\end{abstract}

KEY WORDS: flavonoids, oligosaccharides, nutritive value, rats

\section{INTRODUCTION}

Hypolipidemic effects are attributed to many plant substances, including flavonoids and other polyphenols (Kuo et al., 2005), and to poorly digestible saccharides with prebiotic properties (Delzenne et al., 2002). The results of some works indicate, however, that both types of substances can decrease the nutritional value of diets. Polyphenols, particularly condensed tannins, can decrease the digestibility and biological value of protein (Shahkhialili et al., 1990) while poorly digestible poly- and oligosaccharides can reduce the energy value of a diet (Delzenne et al., 2002). Therefore, the effects of the combined use of both substances on animal performance and gastrointestinal tract metabolism, may be of interest.

\footnotetext{
* Supported by the State Committee for Scientific Research, Grant No. 3P06T 04624

${ }^{1}$ Corresponding author: e-mail: slawus@pan.olsztyn.pl
} 
The aim of the experiment was to investigate the nutritional and physiological effects of separate and combined supplementation of a rat diet with grapefruit flavonoids and inulin.

\section{MATERIAL AND METHODS}

Commercial preparations of grapefruit flavonoids from Cintamani-Poland and Frutafil-Inulin Tex (ORAFTI) were used. Flavonoid extract (FL, 0.3\%) and inulin (IN, 5 and 10\%) were added to a standard casein diet (control) as single (diet FL, IN5 and IN10) or combined (diet FL-IN5 and FL-IN10) additives.

The experiment was performed for 28 days on 48 male Wistar rats of initial body weight $123.8 \mathrm{~g}$. Rats were housed in individual cages and fed ad libitum. Feed intake and body weight were recorded. During the last 5 days faeces and urine were collected, $\mathrm{N}$ retention was calculated as $\%$ of $\mathrm{N}$ intake and apparent biological value (BV) as \% of $\mathrm{N}$ absorbed. At the end of the experiment rats were anaesthetized with urethane and blood was sampled. Total (TC) and HDL cholesterol, triacylglycerols (TAG), glucose, magnesium, calcium and phosphorus concentrations in serum were determined using Alpha Diagnostics sets. Results were subjected to one-way variance analysis, significance of differences was determined by Duncan's multiple range test at the significance level $\mathrm{P}<0.05$.

\section{RESULTS}

A tendency towards lower feed intake and body gain on all diets supplemented with FL and IN, fed singly and in combination, was observed (Table 1) but feed intake was significantly affected only by feeding the FL and FLIN10 diet, and body gain, by the FL-IN10 diet. Feed/body weight gain was not affected. Protein digestibility did not differ among the groups, while N retention $\%$ tended to be higher in all supplemented groups, the difference between IN10 and control being significant. A similar tendency was observed in

Table 1. Growth performance and protein utilization

\begin{tabular}{lccccccc}
\hline & \multicolumn{7}{c}{ Diet } \\
\cline { 2 - 7 } & control & $\mathrm{FL}$ & $\mathrm{IN}_{5}$ & $\mathrm{IN}_{10}$ & FL-IN $_{5}$ & FL-IN $_{10}$ & Pooled \\
\hline Diet intake, g & $439^{\mathrm{a}}$ & $401^{\mathrm{bc}}$ & $419^{\mathrm{ab}}$ & $405^{\mathrm{abc}}$ & $412^{\mathrm{abc}}$ & $381^{\mathrm{c}}$ & 5.00 \\
Body weight gain, g & $150.4^{\mathrm{a}}$ & $139.3^{\mathrm{ab}}$ & $147.7^{\mathrm{a}}$ & $141.1^{\mathrm{ab}}$ & $145.8^{\mathrm{a}}$ & $128.7^{\mathrm{b}}$ & 2.01 \\
Feed/body gain, g/g & 2.92 & 2.88 & 2.84 & 2.87 & 2.83 & 2.96 & 0.02 \\
Protein digestibility, \% & $93.4^{4}$ & 93.0 & 91.8 & 93.0 & 92.8 & 92.9 & 0.26 \\
N retention, \% & $59.1^{\mathrm{b}}$ & $60.6^{\mathrm{ab}}$ & $61.5^{\mathrm{ab}}$ & $65.2^{\mathrm{a}}$ & $61.4^{\mathrm{ab}}$ & $63.1^{\mathrm{ab}}$ & 0.35 \\
$\mathrm{BV}, \%$ & $63.5^{\mathrm{c}}$ & $65.2^{\mathrm{abc}}$ & $66.6^{\mathrm{abc}}$ & $69.95^{\mathrm{a}}$ & $66.0^{\mathrm{abc}}$ & $67.7^{\mathrm{ab}}$ & 0.39 \\
\hline
\end{tabular}


the utilization of nitrogen absorbed, which was significantly higher in groups IN10 and FL-IN10 than in control rats.

Total cholesterol was significantly decreased only in animals fed on the FLIN10 diet as compared with controls, but it was significantly lower in all groups fed on diets containing inulin (singly or in combination) than on the diet containing flavonoids (FL diet) (Table 2). Neither HDL cholesterol, TAG nor glucose were affected by the diet. Among minerals, only the Ca concentration was higher on diet IN10 than on IN5 and FL-IN5; P and Mg concentrations were uniform.

Table 2. Biochemical indices of rat serum

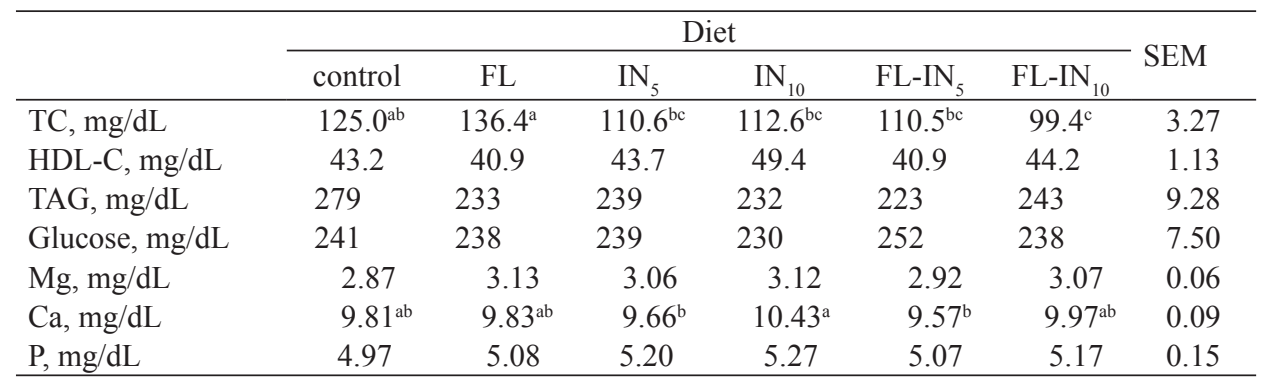

\section{DISCUSSION}

In our study, grapefruit flavonoids decreased feed intake and tended to decrease body weight gain. In the experiment of Kuo et al. (2005) feeding tea polyphenols had no effect on diet intake but depressed growth rate. Inulin fed singly also tended to deteriorate growth performance which is in agreement with the results of Houdijk et al. (1998) but in contradiction with other findings. The worst results were found when animals were fed flavonoids and $10 \%$ inulin in combination. The similar efficiency of feed utilization in all groups may indicate that the nutritional value of diets was not affected by flavonoids or inulin fed either singly or in combination. This conclusion is confirmed by the absence of negative effects on protein digestibility and by a tendency towards higher protein retention. This is not in agreement with the results of Shahkhialili et al. (1990) who found that feeding polyphenols depressed protein digestibility and utilization. These discrepancies may be attributed to differences in the structure of the polyphenols used in different experiments.

Grapefruit flavonoids fed alone did not induce hypolipidaemic and hypocholesterolaemic effects, probably because of a too low dietary level, while such a tendency observed in animals fed on inulin is in agreement with the findings of Delzenne et al. (2002). The effect of inulin was more pronounced when it was fed with flavonoids. 
The similar serum concentrations of minerals despite slightly lower intake of diets containing inulin seem to confirm the suggestion that inulin stimulates absorption of minerals from the gastrointestinal tract (Ohta et al., 1998).

\section{CONCLUSIONS}

Responses of rats to dietary flavonoids and inulin occurred to some extent when these additives were fed either singly or in combination. Flavonoids fed singly negatively affected feed intake, while fed with inulin (10\%), decreased feed intake and weight gain. Inulin fed singly tended to decrease the serum cholesterol concentration, while fed with flavonoids, decreased TC considerably.

\section{REFERENCES}

Delzenne N.M., Daubiol C., Neyrinck A., Lasa M., Taper H.S., 2002. Inulin and oligofructose modulate lipid metabolism in animals: review of biochemical events and future prospects. Brit. J. Nutr. 87, Suppl. 2, S255-S259

Houdijk J.G.M., Bosch M.W., Verstegen M.W.A., Bernepas H.J., 1998. Effect of dietary oligosaccharides on the growth, performance and faecal characteristics of young growing pigs. Anim. Feed Sci. Tech. 71, 35-48

Kuo K.-L., Weng M.-S., Chiang C.-T., Tsai W.-J., Lin-Shiau S.-Y., Lin J.-K., 2005. Comparative studies on the hypolipidemic and growth suppressive effects of oolong, black, pu-erh and green tea leaves in rats. J. Agr. Food Chem. 53, 480-489

Ohta A., Ohtsuki M., Baba S., Hirayama M., Adachi T., 1998. Comparison of the nutritional effects of fructo-oligosaccharides of different sugar chain length in rats. Nutr. Res. 18, 109-120

Shahkhialili Y., Finot P.A., Hurrell R., Fern E., 1990. Effect of food rich in polyphenols on nitrogen excretion in rats. J. Nutr. 120, 346-353

\section{STRESZCZENIE}

Reakcje szczurów na flawonoidy grejpfruta i inulinę dodawane do diety pojedynczo lub lącznie

Szczury o początkowej masie ciała 124 g żywiono przez 28 dni dietą kazeinową bez dodatków (kontrolna) i dietami uzupełnionymi ekstraktem flawonoidów grejpfruta (FL) w ilości 0,3\% oraz inuliną (IN) w ilości 5 i 10\%, dodawanymi osobno lub razem. Rejestrowano spożycie paszy i masę ciała zwierząt oraz oznaczono strawność białka i retencję azotu. Po zakończeniu doświadczenia pobrano krew i oznaczono zawartość cholesterolu (TC), trójglicerydów(TAG), glukozy, $\mathrm{Mg}, \mathrm{Ca}$ i P. FL podawane osobno lub z $10 \%$ IN obniżały spożycie paszy, a FL+IN10 także przyrosty masy ciała. Żaden z dodatków nie wpłynął na strawność białka, natomiast IN sama oraz w połączeniu z FL powodowała poprawę wykorzystania $\mathrm{N}$ strawionego. Poziom cholesterolu nie zmienił się pod wpływem FL, obniżył nieistotnie pod wpływem IN, a istotnie pod wpływem FL+IN10. Obydwa dodatki w sposób nieistotny powodowały obniżenie TAG. 